\title{
JUSTICE FOR THE JUVENILE: THE DECISION TO ARREST AND DUE PROCESS
}

\author{
Samuel M. Davis* \\ The Emerging Juvenile Process
}

Although the courts have devoted an enormous amount of scholarly energy "constitutionalizing" the criminal process, comparatively little attention has been focused on the procedures employed in the system of juvenile justice. Where the courts have been concerned with the juvenile process, moreover, it has been from the point of view of assuring "fairness" in the procedure rather than extending to juveniles the same constitutional protections accorded adults.

Application of less than constitutional standards to the juvenile process had its basis in the premise that juvenile proceedings were civil and not criminal in nature. ${ }^{1}$ Thus, during a child's minority a juvenile court could deprive him of his liberty without the same protections assured an accused in a criminal prosecution. The loss

* Assistant Professor of Law, University of Georgia School of Law. B.A. 1966, University of Southern Mississippi; J.D. 1969, University of Mississippi; LL.M. 1970, University of Virginia.

THE FOLLOWING HEREINAFTER CITATIONS WILL BE USED IN THIS ARTICLE:

Controlling Delinguents, (S. Wheeler ed. 1968) thereinafter cited as Controluing DELINQUENTSl;

JUSTICE FOR THE CHILD (M. Rosenheim ed. 1962) [hereinafter cited as JUSTICE];

F. Remington, Criminal Justice Administration (1967) [hereinafter cited as REMINGTON];

Swanson, Police and Children, in Readings in Juvenile Delinquency 361 (R. Cavan ed. 1969) [hereinafter cited as Swanson];

National Probation \& Parole Association, Standard Juvenile Court Act (6th ed. 1959) [hereinafter cited as JUVENILE ACT];

The President's Commission on LAW ENforcement and ADMinistration of Justice, Commission Report: The Challenge of Crime in a Free Society thereinafter cited as Comaission Report: The Challenge of Crimie];

The President's Commission on LaW Enforcenent and Administration of Justice, Task Force Report: Juvenile Delinguency and Youth CrIME (1967) [hereinafter cited as TASK FORCE REPORT: JUVENILE DELINQUENCY];

Ferster \& Courtless, The Beginning of Juvenile Justice, Police Practices, and the Juvenile offender, 22 VAND. L. REv. 567 (1969) [hereinafter cited as Ferster \& Courtless];

Paulsen, Fairness to the Juvenile Offender, 41 MiNN. L. REv. 547 (1957) [hereinafter cited as Paulsen].

1. See, e.g., the discussion in In re Sharp, 15 Idaho 120, 126-28, 96 P. 563, 564-65 (1908). For a more recent reiteration of the same premise, see In re Gault, 99 Ariz. 181, 192, 407 P.2d 760, 768 (1965), rev'd, 387 U.S. I (1967). 
of liberty was comparable; the constitutional safeguards were not. ${ }^{2}$ This differentiation of treatment was justified under the benign sanction of parens patriae ${ }^{3}$-the state representing not only the interests of society but the interests of the child as well. Instead of relying on the adversary proceeding, the juvenile court relied upon application of the tools of the social sciences in an effort to protect children, to diagnose their problems, and to "help" rather than punish them. The state's role was changed from that of aggressor and adversary to that of benevolent benefactor. ${ }^{4}$ Such a solicitous, nonadversary setting had "little need" for constitutional safeguards. Indeed, one of the supporting goals of the juvenile court movement was to remove the youth from the combative arena of the criminal court with its procedural.formality and stigmatic atmosphere, thereby sparing him the rigor, harshness and public exposure of a criminal trial. The juvenile court scheme was viewed as providing a higher form of justice than could be attained in a criminal court. ${ }^{5}$

2. Paulsen 549. By way of illustrating the attention that courts have paid to rhetoric while disregarding reality, the best analogue comes from Mark Twain. Ken Vinson tells it best:

Huckleberry Finn's uniformed lay mind thought pickaxes were best for digging under the cabin where Jim was trapped. Tom Sawyer knew better; he called for case-knives (table knives): "It don't make no difference how foolish it is, it's the right way-and it's the regular way. And there ain't no other way that I ever heard of, and I've read all the books that gives any information about these things. They always dig out with a case-knife."

Hours later, blisters and impatience rising, a light came to Tom's legal mind. He dropped his knife and in a magisterial voice commanded Huck, "Gimme a case-knife." Huck telis the rest:

"He had his own by him, but I handed him mine. He flung it down and says, 'Gimme a case-knife.' I don't know just what to do-but then I thought. I scratched around amongst the old tools and got a pickaxe and give it to him, and he took it and went to work and never said a word. He was always just that particular. Full of principle."

Vinson, Torts in a Devil's Nutshell, 21 J. LEG. ED. 430, $431-32$ (1969). The incident is taken from M. TWAin, The AdVENTURES OF HuCKLEBERRY FinN (I884).

3. A. Platt, The Child Savers 137 (1969). Almost all of the older cases dealing with juvenile matters endorse the concept of parens patriae-the parental relationship of the state to the child. The discussion in In re Sharpe, 15 Idaho 120, 96 P. 563 (1908), is typical, as is the historical discussion in the more recent case of State v. Monahan, 15 N.J. 34, 104 A.2d 21 (1954). See also District of Columbia v. Jackson, 261 A.2d 511 (D.C. Ct. App. 1970).

4. Alcxander, Constitutional Rights in the Juvenile Court, in Justice 82, 84-85.

5. "Whereas criminal courts exist to convict and dispose of guilty adults, juvenile courts exist to protect and correct delinquent children." Id. at 87-88. The language of the Arizona Supreme Court in Gault reflects the same sentiment:

[J]uvenile courts do not exist to punish children for their transgressions against society. The juvenile court stands in the position of a protecting parent rather than a prosecutor. It is an effort to substitute protection and guidance for punishment, to 
The juvenile court movement, thus meant a diminution of the civil liberties and privacy of the young. The absence of procedural formality and the heavy reliance on paralegal resources marked the juvenile court, in this sense, as an antilegal movement. ${ }^{6}$ This alone, however, is not as damaging as the devastating fact that a delinquency adjudication, on a youngster's level of knowledge understanding and experience, carries the same meaning and sense of soeial disappio-s bation that a criminal conviction carries to an adult - without commensurate constitutional protection. ${ }^{8}$

Although strong feeling still exists in favor of continued reliance on the state's benevolent role of a "protector" concerned with the best interests of the child, ${ }^{9}$ juvenile court procedures have been the target of considerable criticism ${ }^{10}$ which continues to mount. "While recognizing a need for change, earlier critics were hesitant to advocate conferring the trappings of the criminal process upon the juvenile

withdraw the child from criminal jurisdiction and use social sciences regarding the study of human behavior which permit flexibilities within the procedures. The aim of the court is to provide individualized justice for children. 99 Ariz. at 188, 407 P.2d at 765.

6. A. PLATT, supra note 3 , at 4,141 . "In short, this court aimed not to fight the delinquent but to fight delinquency, and not with a legal bludgeon, but with knowledge, science, skill, and devotion." Alexander, Constitutional Rights in the Juvenile Court, in Justice 82, 85.

7. Tappan, Unofficial Delinquency, 29 NEB. L. REv. 547, 548 (1950). In brief, from the youngster's point of view, there is no difference. Certainly substituting the label of "delinquency proceeding" for "criminal prosecution" has no meaning for him. Justice Fortas, writing for the Court in Gault said: "A proceeding where the issue is whether the child will be found to be 'delinquent' and subjected to the loss of his liberty for years is comparable in seriousness to a felony prosecution." 387 U.S. at 36. Moreover, in discussing the application of the constitutional privilege against self-incrimination, he said: "In the first place, juvenile proceedings to determine 'delinquency,' which may lead to commitment to a state institution, must be regarded as 'criminal' for purposes of the privilege against self-incrimination. To hold otherwise would be to disregard substance because of the feeble enticement of the 'civil' labelof-convenience which has been attached to juvenile proceedings." 387 U.S. at 49-50. See also Winburn v. State, 32 Wis. $2 d$ 152, 145 N.W.2d 178 (1966). Empirical studies are available that recount very thoroughly the problem of stigmatization and the tendency of an institutionalized youth to adopt the values and attitudes of a "prison" subculture. See Baum \&. Wheeler, Beconing an Inmate, in Controlung Delinquents 153; Maher, The Delinquent's Perception of the Law and the Community, in Controlling Deunquents 187.

8. Paulsen 549.

9. For a relevant discussion of the competing attitudes, see Judge Musmanno's dissent in In re Holmes, 379 Pa. 599, 610, 109 A.2d 523, 528 (1954). See also In re Winship, 397 U.S. 358, 375-76 (1970) (Burger, C.J., dissenting).

10. Paulsen 547. By this phrase Monrad Paulsen aptly captured the dynamics of what was happening in the juvenile court movement. But what in 1957 was a fair statement has become in 1971-indeed, in the post-Gault years-a gross understatement.

11. For more current criticisms see In re Gault, 387 U.S. I, 12-31 (1967); TASK FORCE Report: JUVEntle Delinguency 29. 
courts. They suggested, rather, the application of traditional, fundamental notions of fairness and due process. ${ }^{12}$ The courts at first agreed with this functional approach. In Kent $v$. United States, ${ }^{13}$ for example, the Supreme Court stated that although it did not hold that a juvenile hearing "must conform with all of the requirements of a criminal trial . . the hearing must measure up to the essentials of due process and fair treatment," 14 which were apparently to be "determined from the requirements of due process and fair treatment, and not by the direct application of the clauses of the Constitution which . . . apply to criminal cases." 15

More recently the Court has placed requisite fairness and due process squarely on the fourteenth amendment, using the provisions of the Bill of Rights as a reference point for determining the requirements of due process. In deciding In re Gault, ${ }^{16}$ for example, the Court reiterated the view taken in Kent but went on to say that the "essentials of due process and fair treatment" standard was "a requirement which is part of the Due Process Clause of the Fourteenth Amendment." "Similarly, the Court has held that proof beyond a

12. "Fairness, is a relative standard. The proper inquiry is: what does fairness require in a children's court case?" Paulsen 550. On this point Judge Alexander agrees: "If all that is wanted is simply justice, it could just as well be meted out to children in any conventional court. The juvenile court was not created to administer justice to children; it was meant . . . to safeguard their supraconstitutional rights . . . ," which include "there social, moral, mental, physical, economic, ethical, and all their natural rights." Alexander, Constitutional Rights in the Juvenile Court, in JUSTICE 82, 88, 90.

13. 383 U.S. 541 (1966).

14. Id. at 562 .

15. Pee v. United States, 274 F.2d 556, 559 (D.C. Cir. 1959) (cited in Kent, 383 U.S. at 562).

16. 387 U.S. 1 (1967).

17. Id. at 30-31. Justice Harlan, on the other hand, would have fashioned the fourteenth amendment test along a more fundamental design: "Among the first premises of our constitutional system is the obligation to conduct any proceeding in which an individual may be deprived of liberty or property in a fashion consistent with the 'traditions and conscience of our people.' "Id. at 67. With this in mind, he said, the Court's task was to "measure the requirements of due process by reference both to the problems which confront the State and to the actual character of the procedural system which the State has created." Id. at 68. The sources for making such a determination are three-fold: "first, the "settled usages and modes of proceeding' ... ; second, the 'fundamental principles of liberty and justice which lie at the base of all our civil and political institutions' ...; and third, the character and requirements of the circumstances presented in each situation." Id. Based on "Fair distillations of relevant judicial history," his test did not use the Bill of Rights provisions as a reference point for determining the essentials of due process, a method of analysis that Justice Black found extremely upsetting. Id. at $61-64$. 
reasonable doubt was required in a delinquency proceeding and is likewise grounded in the fourteenth amendment. ${ }^{18}$

There appears, then, to be a trend away from the idea that all that is required in the juvenile process is a general standard of fairness toward a view that the requirements of fairness and due process, with specific reference to the Bill of Rights, are made necessary by the due process clause of the fourteenth amendment. ${ }^{19}$ This has resulted in an expanding, evolving bag of constitutional rights being accorded to juveniles.

The fountainhead of this movement, of course, was the Gault case, according juveniles the right to counsel, the right to timely and adequate notice of the charges being brought, the privilege against self-incrimination, and the right to confront and cross-examine witnesses against them. ${ }^{20}$ Many areas of the juvenile process, intentionally and by the terms of the opinion were, however, left untouched by the Gault decision, leaving the states and federal agencies a great deal of flexibility and initiative.to bring procedures into line with the spirit of the decision..$^{21}$ Many courts have read Gault to require a great deal more than its mandate. A number, for example, have held that $M$ iranda ${ }^{22}$ warnings must be given to juveniles

18. In re Winship, 397 U.S. 358 (1970). Paradoxically, Winship represents in a sense a return to Justice Harlan's natural law concept of due process, because, as Justice Black points out, the requirement of proof beyond a reasonable doubt is not to be found in the Bill of Rights and, therefore, is not made operable by the fourteenth amendment. Id. at 377. Black's dissent in Winship is a logical, if problematical, consequence of his feeling expressed in Gault that due process means the "law of the land," which in the Gault context he translated as the Bill of Rights. He felt that the particular rights granted in Gault were required by the specific provisions of the Bill of Rights, and only to the extent that the fourteenth amendment made these provisions mandatory upon the states was it relevant. 387 U.S. at 61, 64. To Justice Black it follows naturally that if a particular right is not a requirement of the Bill of Rights, the Court cannot make it so by relying upon the due process clause of the fourteenth amendment standing alone. The paradox of Winship is that it requires, on the basis of the due process clause of the fourteenth amendment, a standard of proof beyond a reasonable doubt in juvenile proceedings involving a violation of criminal law, but it does so without using the Bill of Rights as a reference point.

19. But cf. note 18 supra. In addition, one should note the Supreme Court's decision in McKeiver v. Pennsylvania, 403 U.S. 528 (1971), in which the Court held that the right to jury trial was inapplicable to state juvenile proceedings. This represents the first major setback of the post-Gault era.

20. 387 U.S. at 31-56.

21. Ketcham, Guidelines from Gault: Revolutionary Requirements and Reappraisal, 53 VA. L. REv. 1700, 1706-07 (1967). The Court in Gault very carefully delimited the scope of its decision: "We do not in this opinion consider the impact of these constitutional provisions upon the totality of the relationship of the juvenile and the state. We do not even consider the entire process relating to juvenile "delinquents." " 387 U.S. at 13.

22. Miranda v. Arizona, 384 U.S. 436, 467-73 (1966). 
before any questioning may take place..$^{23}$ Although the Supreme Court ruled in McKeiver v. Pennsylvania ${ }^{24}$ that the Constitution does not require states to provide a jury trial in juvenile proceedings, some jurisdictions have said, either by statute or court decision, that

23. See, e.g., In re Creek, 243 A.2d 49 (D.C. Ct. App. 1968); In re Aaron D., 30 App. Div. 2d 183, 290 N.Y.S.2d 935 (1968); Leach v. State, 428 S.W.2d 817 (Tex. Cl. Civ. App. 1968).

24. 403 U.S. 528 (1971). The Court earlier had been confronted with the issue in DeBacker v. Brainard, 396 U.S. 28 (1969), hut hecause that proceeding was held prior to the decision in Duncan v. Louisiana, 391 U.S. 145 (1968), which applied the sixth amendment right to jury trial to the states through the fourteenth amendment, the Court did not decide the question. The Court already had declared in DeStefano v. Woods, 392 U.S. 631 (1968), that Duncan would not receive retroactive application.

The decision in McKeiver, however, comes as no surprise. Prior to its announcement, the only two members of the Court who could he counted as solidly supporting the right to trial by jury for juveniles were Justices Black and Douglas. Both would have reached the merits in De Backer and would have held that the sixth and fourteenth amendments compel a jury trial in juvenile proceedings in which the delinquent act charged is one that would be criminal if committed by an adult. 396 U.S. at 33-38. In reference to the rights granted juveniles in In $r e$ Gault, Justice Black said: "I can see no basis whatsoever in the language of the Constitution for allowing persons like appellant the henefit of those rights and yet denying them a jury trial, a right which is surely one of the fundamental aspects of criminal justice in the Englishspeaking world." 396 U.S. at 34.

Justice Black's belief that the sixth amendment right to jury trial is applicable to juvenlle proceedings was a further extension of his notion that the rights conferred in Gault were required by the fifth and sixth amendments as made obligatory upon the states by the fourteenth amendment, and not by any vague standard of fairness and due process. In the Gault case, he said: "Where a person, infant or adult, can be seized by the State, charged and convicted for violating a state eriminal law, and then ordered by the State to be confined for six years, I think the Constitution requires that he be tried in accordance with the guarantees of all the provisions of the Bill of Rights made applicable to the States by the Fourteenth Amendment." 387 U.S. at 61 (emphasis added). The only significance to him of the fourleenth amendment's due process clause, relied upon by the majority in Gault, was that "it would, of course, violate due process or the "law of the land' to enforce a law that collides with the Bill of Rights." 387 U.S. at 64.

While the Court has lost Chief Justice Warren and Justices Fortas and Black, critics of juvenile activism have remained on the Court and have been strengthened by the addition of Chief Justice Burger and Justice Blackmun. Chief Justice Burger revealed his feelings in In re Winship, 397 U.S. 358, 375-76 (1970) (dissenting opinion), and Justice Blackmun has now evidenced his leanings by writing the Court's opinion in McKeiver.

Justice Stewart's credentials as an opponent of the expanding role of the Constitution in the juvenile process go back even further. See his dissenting opinion in Gault. 387 U.S. at 78-81 (1967). Justice Harlan had given previous indications that he could not be relied upon to support the right to jury trial for juveniles. In Gault he voiced opposition to any requirement that might "radically alter the character of the juvenile court proceedings." Such requirements, he said, "would contribute materially to the creation in these proceedings of the atmosphere of an ordinary eriminal trial, and would, even if they do no more, thereby largely frustrate a central purpose of these specialized courts." 387 U.S. at 75. Elaborating on this in Winshlp, he intimated disfavor with any action that would, inter alia, "burden the juvenile courts with 
the right is applicable to juvenile proceedings and must be protected. ${ }^{25}$ Several courts have also found, in essence, that a delinquency proceeding is tantamount to a trial; juveniles therefore have the right not to be placed twice in jeopardy for the same offense. ${ }^{26}$ More recently the Supreme Court has held that the standard of proof required in juvenile delinquency proceedings is proof beyond a reasonable doubt, ${ }^{27}$ although some state courts had already reached this result ${ }^{28}$

a procedural requirement that will make juvenile adjudications significantly more time consuming or rigid." 397 U.S. at 375.

By the time the Court decided the jury question, the forces were already deployed and a few skirmishes had taken place. The campaign oratory was over. All that remained was the inevitable counting of the votes.

25. See, e.g., Okla. Stat. Ann. tit. 10, §1110 (Supp. 1970-71). See also Nieves v. United States, 280 F. Supp. 994 (S.D.N.Y. 1968); Commonwealth v. Thomas, 269 N.E.2d 277 (Mass. 1971); Peyton v. Nord, 78 N.M. 717, 437 P.2d 716 (1968); In re McCloud, 8 CRIM. L. ReP. 2340 (R.I. Fam. Ct. Jan. 15, 1971). Of the four cases mentioned only In re McCloud deals directly with the sixth amendment right to trial by jury, holding it applicable to juvenile proceedings. The Massachusetts and New Mexico decisions are based on local statutory law. Nieves involved the consitutionality of waiver of the right to trial by jury. Under federal law the juvenile had a right to trial by jury, but in order to exercise that right, he would have had to elect to he tried as an adult. Election to be tried as a juvenile under the provisions of the Federal Juvenile Delinquency Act, Act of June 25, 1948, ch. 645, $\S 5033,62$ Stat. 857, would have operated as a waiver of the sixth amendment right. The three-judge panel held that this imposed a constitutionally impermissible choice on the juvenile and declared $\S 5033$ unconstitutional insofar as it compelled him to make such a choice. Furthermore, the court held that if the juvenile thereafter elected to he tried as a juvenile, he would have to be afforded the right to a jury trial. The Act has heen amended to conform with the mandate of Nieves. 18 U.S.C. § 533 (1970).

Nothing said in McKeiver v. Pennsylvania changes the above. ArcKeiver merely said that the right to a jury trial is not one of those rights made obligatory upon the states by the fourteenth amendment assessment of due process, the test announced in Gault. This does not prevent the states from affording such a right if they feel compelled, for constitutional or other reasons, to do so.

The great majority of states that have passed on the question, however, have rejected the notion that the right to jury trial is applicable to juvenile procedings. See, e.g., Robinson v. State, 227 Ga. 140, 179 S.E.2d 248 (1971); In re Fucini, 44 Ill. 2d 305, 255 N.E.2d 380 (1970), appeal dismissed, 403 U.S. 925 (1971); Bible v. State, 254 N.E.2d 319 (Ind. 1970); Dryden v. Commonwealth, 435 S.W.2d 457 (Ky. 1968); In re Johnson, 254 Md. 517, 255 A.2d 419 (1969); In re J.W., 57 N.J. 144, 270 A.2d 273 (1970); In re Burrus, 275 N.C. 517,169 S.E.2d 879 (1969), affd, 403 U.S. 528 (1971); In re Daniel D., 27 N.Y.2d 90, 261 N.E.2d 627, 313 N.Y.S.2d 704 (1970); In re Agler, 19 Ohio St. 2d 70, 249 N.E.2d 808 (1969); In re Turner, 253 Ore. 235, 453 P.2d 910 (1969); In re Terry, 438 Pa. 339, 265 A.2d 350 (1970), affd sub nom., McKeiver v. Pennsylvania, 403 U.S. 528 (1971); In re Estes, 73 Wash. 2d 263, 438 P.2d 205 (1968).

26. See, e.g., Hultin v. Beto, 396 F.2d 216 (5th Cir. 1968); Sawyer v. Hauck, 245 F. Supp. 55 (W.D. Tex. 1965); Richard M. v. Superior Court, 4 Cal. 3d 370, 482 P.2d 664, 93 Cal. Rptr. 752 (1971); Tolliver v. Judges of the Family Court, 59 Misc. 2d 104, 298 N.Y.S.2d 237 (Sup. Ct. 1969); Collins v. State, 429 S.W.2d 650 (Tex. Ct. Civ. App. 1968).

27. In re Winship, 397 U.S. 358 (1970).

28. Thomas v. State, 121 Ga. App. 9l, 172 S.E.2d 860 (1970); In re Urbasek, 38 III. 2d 535, 232 N.E.2d 716 (1967); People v. Archie, 105 lll. App.2d 211, 245 N.E.2d 59 (1969). 
and one state had enacted a statute incorporating the reasonable doubt standard in juvenile proceedings. ${ }^{29}$

The above enumeration is illustrative and not exclusive or exhaustive of the emerging "constitutionalized" juvenile process. Today there can be no doubt that the juvenile court is a miniature criminal court-as it has been disparagingly described ${ }^{30}$-although this ought to be accepted without an abjuration of the entire juvenile court movement. ${ }^{31}$

Thus, the trend evidenced by Gault and its progeny has been marked by a "tendency of these doctrines to push on to their logical conclusion." 32 What their logical conclusion is, of course, would require the exploration of the whole breadth of juvenile law, and the answer could never be too precise, because, like an amoeba, it is constantly changing shape and growing in size and complexity as the constitutional issues are analyzed and articulated. The purpose of this article, therefore, is to examine only one-though crucial-part of the whole: the power of the police to intervene in the lives and conduct of youth, to take them into custody, and the means of protecting a juvenile's rights-including a determination of what those rights are-if he is taken into custody.

\section{The Police and Juvenile Custody}

\section{The Decision to Take a Youth into Custody}

The decision to invoke the criminal process by arresting someone is not a mechanical procedure, but rather involves a complicated,

29. ILL. REV.STAT. ch. 37, \& 704-6 (1969).

30. Hennings, Effectiveness of the Juvenile Court System, 23 Fed. Prob. 3, 7 (1959).

31. For support of the notion that the Court in its overzealous activism has swallowed the last vestige of the philosophy of the juvenile court, see Chief Justice Burger's dissent in Winship. 397 U.S. at 375-76. Gault, however, supports the countervailing notion that the juvenile court philosophy and constitutional rights traditionally denied application in the juvenile court are compatible: "As we shall discuss, the observance of due process standards, intelligently and not ruthlessly administered, will not compel the States to abandon or displace any of the substantive benefits of the juvenile process." 387 U.S. at 21. And again: "We do not mean by this to denigrate the juvenile court process or to suggest that there are not aspects of the juvenile system relating to offenders which are valuable. But the features of the juvenile system which its proponents have asserted are of unique benefit will not be impaired by constitutional domestication." Id. at 22.

32. W. Schaefer, The Suspect and Society 27 (1967). Judge Schacfer was referring to new constitutional doctrines that impinge upon police investigation in criminal cases, but his remarks seem analogous to a similar phenomenon occuring in the juvenile process. The logical flow of the Gault rationale appears to have been slowed, however, by the Supreme Court's decision in McKeiver v. Pennsylvania, 403 U.S. 528 (1971). 
though informal and perhaps unconscious, policy-making process. The police officer must assimilate, often quickly and under pressure, what conduct is in fact criminal, the seriousness of the incident, and the appropriate response. The complexity of the process is compounded when dealing with juveniles, since to the existing morass is added a great deal of uncertainty concerning the proper role of the police in handling juveniles, ${ }^{33}$ for which the great majority of jurisdictions in this country make no special provision..$^{34}$ Traditional limitations placed on police dealing with adults suspected of crime-in particular, that there be sufficient knowledge in the possession of the officer that would justify his interference-have not been the concern of officers handling juveniles. The concern rather has been to "protect" the youth and to instill in him respect for law enforcement. ${ }^{35}$ In addition, because juvenile proceedings are not regarded as criminal in nature, the police exercise considerably more discretion in dealing with juveniles than is exercised with adults. ${ }^{36}$

The continued reliance on the parens patriae concept has led most police officers to conclude that the limitations placed on them in the investigation of adult crimes do not apply in the investigation of youth of fenses ${ }^{37}$ which makes encounters between youth and the police a

33. The President's Commission on Law Enforcement and Administration of JUSTICE, TASK FORCE REPORT: THE POLICE 13-14 (1967).

34. See Luger, The Youthful Offender, in TASK Force Report: Juvenile Delinquency 119,121 .

35. REMINGTON 959. Again, all of the old and a number of the more recent cases emphasize the "protective" rather than punitive nature of the juvenile process. See, e.g., State v. Monahan, I5 N.J. 34, 104 A.2d 21 (1954), in which the court quotes from the case of In re Morin, 95 N.H. 518, 520, 68 A.2d 668, 670 (1949), saying: "We think it sufficiently plain that the act in question is designed to permit the exercise of the powers of state as 'parens patriae,' for the purpose of rehabilitating minor children, and not of punishing them for the commission of a crime. 'It is generally held that the purpose of such statutes is not penal, but protective.' " 15 N.J. at 38,104 A.2d at 23.

36. Wilson, The Police and the Delinquent in Two Cities, in Controlung Delinquents 9, 10. For an analytic treatment of the whole area of police discretion, see Tieger, Police Discretion and Discriminatory Enforcement, 1971 DUKE L.J. 717 and Ferster \& Courtless 57583.

37. REMINGTON 969. Indeed, this belief has been fostered to some extent in the courts, In re James L., Jr., 25 Ohio Op. 2d 369, 194 N.E.2d 797 (Cuyahoga County Juv. Ct. 1963), and in the legislative position that taking a juvenile into custody does not amount to an arrest. See, e.g., Juvenile ACt § 16; ILl. ANN. STAT. ch. 37, § 703-1(3) (Supp. 1971); MinN. Stat. ANN. § 260.165 (1971); OHto REv. CODE ANN. \$2151.31 (Page Supp. 1970); WIS. StAT. ANN. § 48.28(2) (1957). See also Ferster \& Courtless 583-89. However, the scope of the Gault decision is still expanding, see notes 21-32 supra, and it is too soon to conclude how far-reaching the impact of Gault will be. With the extension of Gault's mandate into the investigatory stages of juvenile proceedings, vis-a-vis the Miranda requirements, see note 23 supra, law enforcement 
crucial stage of the juvenile process. A minor's initial contact with the juvenile justice system is with the police and it sets in motion forces of informal decision making that may determine whether he is to be entangled in the net of the juvenile process. In many cases he has been caught violating the law or is being sought in connection with a particular crime, but many instances occur wherein no particular act has been committed-that is, the policeman's sixth sense tells him that something is amiss. ${ }^{38}$ In such instances, the officer can respond in a number of ways. He can do nothing; he can stop and ask the juveniles their names, their addresses, and their destination; he can search and order them to disperse; he can send or take them home and warn their parents to keep them off the street; or, he may take them to the station for further questioning or checking. ${ }^{39}$

An officer's response to a street situation may be regulated to some degree by departmental practice, which may be either expressly or tacitly un.eerstood, ${ }^{40}$ but is also affected by more subtle factors. Suspecting that something has happened or is about to happen, but

officers apparently will apply to juveniles the same standards telating to the law of arrest that are now applied in the case of adults. The most that can be said now is that police are uncertain about what is required of them in taking a juvenile into custody. $C f . G_{A}$. CODE ANN. $\$ 24 A-$ 1301(b) (1971) which provides that taking a juvenile into custody is not deemed an arrest "except for the purpose of determining its validity under the Constitution of this State or of the United States." This seems to imply that the law of arrest shall apply to juveniles in the same manner in which it is applicable to adults.

38. Commission Report: The Challenge of Crime 78. See also R. Maclver, The Prevention and Control of Delinquency 139 (1966).

39. Commission Report: The Challenge of Crime 78.

40. Id. Police response to on-the-street juvenile situations varies greatly from one department to the next. Swanson 361. The degree of discretion exercised depends to a large extent on the characterization of the department in terms of departmental policy, attitudes, and philosophy. A comparison of two departments-one a large eastern department characterized as a "fraternal" department, and the other a large western department, characterized as a "professional" department-revealed that the highly professional department exercised less discretion and responded to juvenile problems with greater formality (i.e., more arrests and more referrals to juvenile court), whereas the fraternal department exercised far more discretion and tended to dispose of many juvenile malters without any further official action or referral to juvenile court or any other agency. The professional department was described as "one governed by values derived from general, impersonal rules which bind all members of the organization and whose relevance is independent of circumstances of time, place or personality." On the other hand, the nonprofessional or fraternal department was described as one that "relies to a greater extent on particularistie judgments-that is, judgments based on the significance to a particular person of his particular relations to particular others." Wilson, The Police and the Delinquent in Two Cilies, in Controlling Delinquents 10-12. See also J. WILson, VARIETIES OF POLICE Behavior 111-18, 217-18 (1968). 
with nothing concrete upon which to select a course of action, he may be guided by his subjective attitudes toward, for example, members of a particular race, length of hair, style of clothes, or other qualities of appearance, as well as the reaction and attitude of the juvenile himself-whether he is cooperative and respectful or impudent, defiant or indifferent. ${ }^{41}$ In the absence of any "legal" basis, reticence or equivocation on the part of the youth may well be the basis of an arrest. 42

In street encounters there may be a convergance of conflicting attitudes. Police officers, for example, view as essential to effective Jaw enforcement the power to stop persons on the street, to ask questions, and if the occasion seems to require it, to detain them for further questioning. ${ }^{43}$ The officer on the street may also view his job as maintaining order and the established routine. Anything that appears to be a departure from the routine gives cause for suspicion and the officer is likely to intervene. If the officer's authority is questioned, moreover, this may manifest to him another departure from the routine and a threat to established order. Such a challenge may be met with a rather severe response. ${ }^{4}$

A youth usually has preexisting attitudes toward the police that will be confirmed or changed by his initial encounter with a police officer. Much, therefore, may depend upon the attitude of the officer himself - whether it evokes respect or antagonism. The interaction of these attitudes may determine whether the child will be taken into custody or released. 45

Juveniles possess unique characteristics that demand a specialized form of handling. ${ }^{46}$ Youth are very impressionable, and when they

41. Commission Report: The Challenge of Crime 78; Ferster \& Courtless 578-79. See generally Comment, Socio-Legal Aspects of Racially Motivated Police Misconduct, 1971 DUKE L.J. 751.

42. TASK FORCE REPORT: THE POLICE, supra note 33, at 186.

43. Commission Report: The Challenge of Crime 93. See Terty v. Ohio, 392 U.S. 1 (1968); Sibron v. New York, 392 U.S. 40 (1968). See also In re Lang, 44 Misc. 2d 900, 255 N.Y.S.2d 987 (Fam. Ct. 1965).

44. P. Chevigny, Poutce Power 276 (1969). The policeman exercises an authoritative function: "He suppresses crime, apprehends offenders, and preserves the public peace. He protects the rights of the individual. He sets the tone of law enforcement for the area he patrols." Swanson 362 . He therefore regards any challenge to his exercise of this function as a serious matter. See J. WiLson, supra note 40 , at 217.

45. National, Council on Crime and Delinguency, Standards and Guides for the DETENTION OF CHILDREN AND YOUTH 23 (1961). 21.

46. Luger, The Youthful Offender, in TASK Force Report: JuvenILe DeLINQuency 120- 
first encounter the juvenile justice system they may feel all alone and view the police, as well as other forms of authority, as demanding, judgmental and perhaps hostile. 47 The young, because they are especially vulnerable to influence, however slight, must be handled with a great deal more circumspection and understanding than an adult offender. It is important that the impression of the administration of justice that minors get at this point be one of fairness, for if this impression is formed, the process of rehabilitation has already commenced. ${ }^{48}$ Otherwise, he may be imbued with a disrespect for lawful authority and a sense of bitter resentment for the system of justice. ${ }^{49}$ The concern for the consequences flowing from the encounter between the youth and police is thus justified. Implicit in this concern, however, is the officer's view of himself as a vital, functioning part of the rehabilitative process..$^{50}$

\section{The Jurisdictional Basis for Taking a Youth into Custody}

Too little attention has been paid to the relationship between state power and individual liberty where the juvenile is concerned. The relationship is crucial because, given the protective role of the juvenile court, when authority is exercised to do something for a youth, something must be done to him as well.51

One of the characteristics of the juvenile justice system is that the scope of its jurisdiction, derived from the original scheme of the juvenile court concept, is very broad-to take in all youths in need of help, for whatever reason. Discarding momentarily the area of neglect and dependency jurisdiction, the broad jurisdictional scope includes not only the area of conduct which if committed by an adult would be criminal, but also a rather large area of other, more general, youthful misbehavior. The intake of a typical juvenile court includes all sorts of youths who are in trouble, although the "trouble" may consist simply of youthful criminality - that is, conduct which society deems unlawful when engaged in by youth, but not when committed by adults-truancy, or something less serious. Such an approach seeks to enforce the criminal code as well as a more general code of

47. Ketcham, Legal Renaissance in the Juvenile Court, 60 Nw. U.L. REv. 585, 595 (1965).

48. Paulsen 551. See also R. MACI VER, supra note 38, at 139-40; Swanson 361-62.

49. S. Wheeler \& L. Cottrell, Juvenile Delinquency 33 (1966). See also Commission Report: The Challenge of Crime 79.

50. REMINGTON 959.

51. Paulsen, The Expanding Horizons of Legal Services-II, 67 W. VA. L. REv. 267, 269 (1965). See also J. Kenny \& D. Pursuit, Police Work With Juveniles 47 (3d ed. 1965). 
juvenile conduct which embraces duties owed by youth both to parents and school authorities. Enforcement of a more general code of behavior was marked by the advent of the "incorrigibility" status-wherein if the youth exhibits such an attitude of defiance that he cannot be controlled by his parents or school authorities, the juvenile court may intervene in situations amounting to something less than the violation of criminal laws..$^{52}$

Perhaps the powers of police to intervene in the conduct of juveniles ought to be broader than it is in the case of adults. Perhaps an officer should be able to take a juvenile into custody when he reasonably believes that the child is delinquent or in need of help or supervision for whatever reason; otherwise, the police may be powerless to act in situations where their knowledge indicates that a child is delinquent but falls short of knowledge sufficient to show a violation of law. ${ }^{53}$ Viewed in this light, broad authority is necessary for the protection of youth and is not necessarily a measure for abrogating their rights. However, even if the police should have this power, the circumstances under which a youth is taken into custody in the first place must be a major area of concern, particularly in light of the need to inquire into the relationship between state power and individual liberty. As noted, most officers do not think that limitations placed on their dealings with adults are applicable when handling juveniles. ${ }^{51}$ Indeed, this is consistent with the notion that a juvenile is not "arrested," but is "taken into custody" which implies a protective and not punitive form of detention. ${ }^{55}$

52. TASK Force Report: Juvenile Delnquency 22. Most "incorrigibility" statutes are similar to New York's:

"Person in need of supervision" means a male less than sixteen years of age and a female less than eighteen years of age who does not attend school in accord with the provisions of part one of article sixty-five of the education law or who is incorrigible, ungovernable or habitually disobedient and beyond the lawful control of parent or other lawful authority. N.Y. FAM. CT. ACT $\$ 712$ (b) (McKinney Supp. 1970-71).

For a discussion of the varying police role in the different jurisdictional contexts, see Ferster \&. Courtless 584-89.

53. Implicit in this suggestion, of course, is a new definitional concept of "delinquency." Traditionally, delinquency included all forms of juvenile behavior that were regarded as undesirable, including what otherwise would be criminal conduct, incorrigibility, truancy, running away from home, and being in need of supervision. See, e.g., Miss. CoDE ANN. $\$ 7185-02$ (g) (Supp. 1970). More recent formulations, however, have limited "delinquent" conduct to violations of local, state, or federal laws and have placed all of the other forms of conduct mentioned above in the category of "persons in need of supervision." See, e.g., CAL. WeLF. \& INST'NS CODE $\$ \S 601,602$ (West 1966).

54. See note 37 supra.

55. See, e.g., JUVENILE ACt § 16; ILl. ANn. Stat. ch. 37, § 703-1(3) (Supp. 1971); MinN. Stat. ANN. \$260.165 (1971); Ohto Rev. Code ANN. \$2151.31 (Page Supp. 1970); Wis. 
The circumstances under which a youth may be taken into custody are quite broad. The Standard Juvenile Court Act, for example, provides that a child may be taken into custody when he violates a law in the presence of the officer, when there are reasonable grounds to believe that he has committed an act which if committed by an adult would be a felony, when he is "seriously endangered in his surroundings," and when there are reasonable grounds to believe that he has run away from home. ${ }^{56}$ Exactly what circumstances would indicate to a police officer that a child was "seriously endangered in his surroundings" is not at all clear.

California has two statutes which, in addition to others, delimit the juvenile jurisdiction, and provide a poignant example of the problem. The first provides that any person under the age of twentyone who violates the law, or who fails to obey a lawful order of the juvenile court, is within the jurisdiction of that court, which may adjudge him to be its ward. ${ }^{57}$ The second provides that one under the age of twenty-one who habitually disobeys the proper orders of his parents or guardian, or who is a truant, or "who from any cause is in danger of leading an idle, dissolute, lewd, or immoral life," is within the jurisdiction of the juvenile court..$^{58}$ If any situation is more tenuous than one in which a youth is "seriously endangered in his surroundings" it is one in which the youth is "in danger of leading an idle, dissolute, lewd, or immoral life." This expression of concern, even though founded on the worthy desire to protect the young from themselves, takes in a great range of conduct-indeed, a large part of the problem is that one meets difficulty in determining exactly what conduct is included. Certainly if such language served as the basis of a criminal conviction, it would be subject to a constitutionally based vagueness challenge. ${ }^{59}$

STAT. ANN. $\S 48.28(2)$ (1957), all of which provide that taking a juvenile into custody is not deemed an arrest. Ferster \& Courtless, who have conducted considerable research in this area, relate that some thirty-six jurisdictions employ the substituted phraseology. Ferster \& Courtless 583-84 \& n.76. Of these thirty-six, fifteen specifically state that taking a juvenile into custody does not constitute an arrest. Id. at 584 \& n.77.

56. Juvenile ACt $\S 16$. See also D.C. Code ANN. $\S 16-2309$ (1970 D.C. Code Leg. \& Ad. Serv. 89).

57. CAL. WeLf. \& INST'NS CODE $\S 602$ (1966).

58. Id. $\S 601$.

59. Paulsen 556. Paulsen has more recently suggested, however, that the definitions are vague because the conduct they seek to describe is vague. The standard for measuring such conduct, he says, "does not admit of a more certain formulation." Paulsen, The Delinquency. Neglect, and Dependency Jurisdiction of the Juventle Court, in JusmCE 50. See also Dorsen 
Vagueness, however, is not the only problem of this type of statute. In In re Daniel $R .{ }^{60}$ for example, a California juvenile court found that a sixteen year old boy who admitted having sold marijuana was in danger of leading a "dissolute life." Although this decision was reversed for lack of sufficient evidence, the appellate court expressed no concern over the fact that the juvenile had been taken into custody with neither warrant nor probable cause. ${ }^{61}$ This is precisely the type of case that leads police officers to believe that the usual limitations inherent in the handling of adult offenses do not apply when they are dealing with juveniles. The broad jurisdictional power allows officers to take juveniles into custody for criminal law violations under circumstances in which they would not be permitted to arrest adults. In a case such as In re Daniel $R$., the police, in the absence of reasonable grounds to believe that the youth had committed a criminal offense, could rely instead on the much broader "protective" jurisdiction that permits a youth to be taken into custody where he is "seriously endangered in his surroundings" or is "in danger of leading an idle, dissolute, lewd, or immoral life." This is not to say that the broad grant of jurisdiction is improper per se. Many young people are in need of help for reasons that fall short of criminal behavior, and their problems ought to be brought to someone's attention. But when juxtaposing state power with individual liberty, more precision is required than is found in the description of a youth as being "in danger of leading an idle, dissolute, lewd, or immoral life."

The problem is compounded, moreover, by the fact that most youths are undoubtedly taken into custody without a warrant, normally when they are caught in the act of committing an offense or when an officer observes circumstances that seem to require such action. ${ }^{62}$ Because the decision to take a youth into custody is primarily a police decision, the disparity between the handling of adults and juveniles is perhaps greatest at this point. ${ }^{63}$ Admittedly, a police

\& Rezneck, In re Gault and the Future Juvenile Law, 1 FAm. L.Q. 1, 33 (1967). In fact, however, the language in section 601 was held to be unconstitutional in Gonzalez v. Mailliard, No. 50424 (N.D. Cal., Feb. 9, 1971), excerpted in 5 Clefaringhouse REv. 45.

60. Unreported (Orange County Super. Ct., Nov. 5, 1968).

61. 274 Cal. App. 2d 749, 754, 79 Cal. Rptr. 247, 250 (1969).

62. F. Sussman, Law of Juvenile Delinguency 33 (3d ed. F. Baum 1968).

63. REMINGTON 972. Despite the fact that most arrests are made without warrant, the criminal law indicates a clear preference for the detached judgment of a magistrate rather than the subjective judgment of the policeman on the beat. See Giordenello v. United States, 357 
officer ought to possess the flexibility of authority to take someone-adult or juvenile-into custody when he has a reasonable belief that the person has violated a law; but whether he-should have the same power where more subtle decisions are involved-such as whether a child is "in danger of leading an idle, dissolute, lewd, or immoral life" - is highly questionable.

The protective aura that surrounds the whole juvenile court philosophy-the spirit of parens patriae-is not so benevolent, however, that it can embrace at the same time the best interests of the child on the one hand and the denial of precious rights on the other. One writer has observed that our system of justice cannot accommodate a disparity in the rights accorded to two classes of people-adults and children-on the basis of labels that we attach to each. ${ }^{64}$ Yet he would still grant to police broader power to take youths into custody than that permitted in the case of adults, because otherwise the police would be without authority to intervene in a situation where their knowledge indicates that a child is delinquent, but falls short of knowledge sufficient to show a violation of law. This is desirable as a "protective" measure and not as a measure for depriving juveniles of their rights. ${ }^{65}$ The existence of such power, however, enables the police, as in Daniel $R$., to take a juvenile into custody for what ultimately amounts to a criminal violation, while relying, in the absence of the requisite reasonable cause, on a statute that grants the power to take a youth into custody where he is in danger of leading a "dissolute life." 66

U.S. $480,486.87$ (1958). The requirement of a warrant is a safeguard that is by-passed whenever an arrest without warrant is made. Beck v. Ohio, 379 U.S. 89, 96 (1964). This is not to say that arresting without a warrant is a reprehensible practice. The message imparted by the criminal law is merely that a warrant ought to be obtained wherever practicable. Wherever the circumstances permit a choice to be made, that choice ought to be exercised in favor of obtaining a warrant, issuance of which is based on a magistrate's impartial, objective judgment. See Wong Sun v. United States, 371 U.S. $471,479-80$ (1963).

64. There is a relationship between the rights of a child and the treatment given him by the juvenile court. If the result of an adjudication of delinquency is substantially the same as a verdict of guilty, the youngster has been deprived of his constitutional rights by false labeling. We cannot take away precious legal protection simply by changing names from "criminal prosecution" to "delinquency proceedings." Paulsen 550.

65. Id. at 551. In this same vein Paulsen also adds: "[M]oreover, limiting delinquency to violations of criminal law also involves resort to uncertainties. Consider 'disorderly conduct,' 'vagrancy,' 'disturbing the peace'-each a crime in spite of its lack of precision." Paulsen, The Delinquency. Neglect, and Dependency Jurisdiction,of the Juvenile Court, in Justice 5051.

66. In re Daniel R., 274 Cal. App. 2d 822, 79 Cal. Rptr. 247 (1969). 
Somewhere in this morass of conflicting ideals, arising out of genuine concern for the juvenile's constitutional rights, personal liberty, protection and general welfare, there ought to be a point where a balance can be struck. Such a resolution is possible and proceeds from the belief that the police ought to have broad powers to take young people into custody. The danger inheres not in the existence of the power itself, but in the manner in which it is exercised. In brief, the power ought simply to be exercised with a great deal more circumspection. Most states have statutes that allow police officers to take juveniles into custody under circumstances where they either are endangered by their surroundings or otherwise are exhibiting moral dissolution. ${ }^{67}$ These statutes indicate, as has already been acknowledged, that the decision to take a youth into custody is regarded as primarily a police decision; ${ }^{68}$ however, should it be solely a police decision when the broad jurisdictional power is invoked to take into custody a youth who is "in danger of leading a dissolute life?" Police officers generally are poorly equipped to make this sort of decision, and the possibility of abuse is too hazardous to allow them to exercise it without check. To be sure, juveniles in "trouble" should get help, but someone other than the officer in the street ought to assume the primary responsibility in the decision-making process. ${ }^{69}$

One such provision is contained in New York's juvenile jurisdiction statute which provides that a person under the age of sixteen may be taken into custody without a warrant only when he is committing an act which, if performed by an adult, would justify an arrest. ${ }^{70}$ Thus, the statute does not authorize custodial detention of a juvenile on the ground that he is in need of supervision, because

67. The District of Columbia, for example, makes the following provision in its code:

A child may be taken into custody-

(3) by a law enforcement officer when he has reasonable grounds to believe that the child is suffering from illness or injury or is in immediale danger from his surroundings, and that his removal from his surroundings is necessary. . . .

... . D.C. CODE ANN. \$ 16-2309 (1970 D.C. Code Leg. \& Ad. Serv. 89).

See also Juvenile Act $\$ 16$; CAL. Welf. \& Inst'Ns Code $\$ 601$ (West 1966); MinN. Stat. AnN. \$ 260.165 (1971); Ohio Rev. Code ANN. \$2151.31 (Page Supp. 1970); IVis. Stat. ANN. § 48.28 (Supp. 1971-72).

68. See note 63 supra.

69. The exercise of responsibility here ought to be genuine, rather than the sort of "rubber stamp" authorization by magistrates that commonly occurs in the criminal process.

70. N.Y. Judictary LaW $\S 721$ (McKinney Supp. 1970-71) (Family Court Act). 
in such situations "there is no such urgency that the matter may not be dealt with initially by summons." 71

New York does recognize that juveniles need protection in situations involving less than criminal behavior, but its approach differs from that of most states. Without a warrant or summons a policeman on the beat and lodging it with the juvenile court judge decision that the youth requires supervision. If the youth is to be taken into custody, the officer must obtain a summons from a judicial authority and must, presumably, present to that authority the facts supporting his belief that the minor requires supervision.

As the Committee Comment to the New York statute explains, no situation in which a youth requires supervision is so compelling that it cannot be handled through use of a summons. ${ }^{72}$ This provides a practical, workable approach, removing the decision from the policeman on beat and lodging it with the juvenile court judge who knows more about youth, youth problems, and the realities of the juvenile justice system and is better able to assimilate this knowledge and place it in a legal perspective. The criminal justice system deemphasizes the competence of the police to weigh evidence and make the on-the-street decision to arrest, substituting therefor a warrant wherever possible. ${ }^{73}$ The juvenile process should demand no less a standard. Requiring a summons to issue whenever protective jurisdiction is to be invoked seems to be reasonable in light of the gravity and sophistication of the decision to be made..$^{74}$

\section{Procedural Requirements at Other Stages of the Juvenile Custodial Process-In Custody Treatment}

Analysis of developments in other stages of the juvenile custodial process amplifies the need for imposing stricter procedural requirements on the decision to take a youth into custody. In terms of protecting a juvenile's rights, the process that begins immediately after a youth is taken into custody is perhaps an area of even greater

71. See the Committee Comment following N.Y. Judiciary Law $\S 721$ (McKinney Supp. 1970-71).

72. Id.

73. See note 62 supra.

74. Cases may arise, however, where the child's immediate safety is in peril, and in such cases it may be necessary for the officer to act immediately to prevent harm from coming to the child. See, e.g., State v. Hunt, 2 Ariz. App. 6, 406 P.2d 208 (1965), where the officer responded to the call of a babysitter who had discovered a five-ycar-old child lying on the floor of a furnace room, her hands tied behind her back, her head under the hot water heater, 
concern than the custody decision. ${ }^{75}$ The procedural aspects of the juvenile process, including police investigation and interrogation, are confusing to both children and their parents, whose reaction is frequently one of bewilderment and wonder.$^{76}$

As has already been noted, most youths are taken into custody without warrant or summons. ${ }^{77}$ One immediate problem is whether the youth should be released into the custody of his parents or held for further investigation. Because children are often held at police stations on suspicion or for investigation for indefinite periods of time, some states, to alleviate the potential harm of unnecessary detention, have followed the example set forth in the Standard Juvenile Court $\mathrm{Act}^{78}$ which provides that if a child is taken into

and blood on her face from what appeared to be strap marks. Section 16(c) of the Standard Juvenile Court Act contains a somewhat vague provision that would permit the officer to remove the child from his surroundings where he is faced with immediate danger. Even New York has a statute that would permit emergency removal in such a case. N.Y. JUDICIARY LAw $\S 1024$ (McKinney Supp. 1970-71). In these instances the officer is acting out of concern for the child's welfare, and there may be other situations that would evoke the same concern and demand the same immediate response. But what is involved is a matter of degree, and the officer initially is charged with determining the degree and electing a course of action. Whenever practicable, however, he ought to obtain a warrant or summons, and the impartial magistrate ought to be the one who determines the course of action to be taken.

75. See Paulsen 551 .

76. Studt, The Client's Image of the Juvenile Court, in Justice 204-05.

77. See notes 62-63 supra and accompanying text.

78. F. Sussman, supra note 61, at 33-34. See Juvenile Act § 16. The National Council on Crime and Delinquency also has made recommendations to this effect. National CouncIL on CRIMe and Deunquency, supra note 45, at 23-24.

New York's statute provides as follows:

(a) If a peace officer takes into custody under section seven hundred twenty-one or if a person is delivered to him under section seven hundred twenty-three, the peace officer shall immediately notify the parent or other person legally responsible for his care, or the person with whom he is domiciled, that he has been taken into custody.

(b) After making every reasonable effort to give notice under paragraph (a), the peace officer shall

(i) release the child to the custody of his parent or other person legally responsible for his care upon the written promise, without security, of the person to whose custody the child is released that he will produce the child before the family court in that county at a time and place specified in writing; or

(ii) forthwith and with all reasonable speed take the child directly, and without his first being taken to the police station house, to the family court located in the county in which the act occasioning the taking into custody allegedly was done. . . ; or

(iii) take the child to a place designated by rules of court for the reception of children.

(c) In the absence of special circumstances, the peace officer shall release the child in accord with paragraph (b)(i). 
custody, with or without warrant, his parents or guardian shall be notified immediately. The Act further provides that unless there is some compelling reason why he should not be released, the youth shall be released in parental custody upon a written promise to produce him in court at the designated time. ${ }^{79}$ With these special release provisions for juveniles and the emphasis on releasing them into parental custody, bail for juveniles has not been a question of immediate concern. It might be argued that bail should not be accorded a youth as a matter of right, not due to characterization of a juvenile proceeding as civil rather than criminal in nature, but because the youth may be in need of care and supervision that might be denied him without proper inquiry into the conditions and environment into which he would be released..$^{80}$ The expanding "constitutionalization" of the juvenile process, on the other hand, may very well include the right to release on bail to the extent that it is enjoyed by adults. ${ }^{81}$

Another problem arises where the police wish to detain a juvenile for further questioning. Although a reading of the cases and literature following Gault revealed its inescapable impact on the rights of juveniles during the investigatory stages, questions were inevitable as a consequence of the Court's own. language..$^{22}$ Did Gault, for example, require police officers to give Miranda warnings to juveniles? If not, should they do it anyway? What role, if any, were parents to play during the investigatory stage? Many states answered these and other questions by extending Gault beyond what it specifically required, indicating again the tendency of Gault to be pushed to its logical conclusion. ${ }^{83}$ Oklahoma, for example, enacted a

N.Y. FaM. CT. Act § 724 (McKinney Supp. 1970-71). See also lll. AnN. Stat. ch. 37, § 703-2 (Supp. 1971); MinN. Stat. ANN. § 260.171 (Supp. 1971); W1S. Stat. ANN. $\S 48.29$ (Supp. 1971-72).

79. JUVENILE ACT $\S 16$.

80. Pauisen 552.

81. One court has so held. Trimble v. Stone, 187 F. Supp. 483 (D.D.C. 1960). See also GA. CODE ANN. \& 24A-1402(c) (1971).

82. We do not in this opinion consider the impact of these constitutional provisions upon the totality of the relationship of the juvenile and the state. We do not even consider the entire process reiating to juvenile "delinquents." For example, we are not here concerned with the procedures or constitutional rights applicable to the pre-judicial stages of the juvenile process. . . . 387 U.S. at 13.

83. See notes 21-29 supra and accompanying text. One must be aware, however, that the states (through legislation as well as court action) that have extended Gault represent the vanguard of a movement to give increased meaning to the emerging juvenile process. Many states have not answered the lingering questions and have not reached some of the "logical conclusions" flowing from the Gault decision. 
statute after the Gault decision which provides that information gained by the questioning of a child is inadmissible unless the questioning is conducted in the presence of the child's attorney or legal custodian and only after they have been fully advised of their constitutional and legal rights, including the right to a trial by jury, right to counsel, and the right to have counsel appointed by the court and paid out of the court fund if the party cannot afford one. ${ }^{84}$ Thus, the Oklahoma statute requires Miranda-type warnings but, oddly enough, does not provide that the child and his parents be warned of their right to remain silent ${ }^{85}$ and that this right may be exercised at any time. The California statutes provide for full Miranda warnings, but require, in addition, that the same warnings be given to a juvenile and his parents by a probation officer if the juvenile is taken before the probation authority. ${ }^{86}$

Although New York's statutory law does not require that juveniles be given Miranda warnings, ${ }^{87}$ its courts have held that they must be warned of their constitutional rights before any questioning can take place, and have placed great emphasis on the presence or absence of the parents, particularly where the youths are very young. ${ }^{88}$ Thus, in a recent case a New York court held inadmissible, statements made to police after a youth had been given the Miranda warnings in the absence of his parents. ${ }^{89} \mathrm{~A}$ child's confession has also been held inadmissible after he had been warned of his constitutional rights, because the court found no effective waiver, the place of questioning - the police station - was not a statutorily approved place

84. OKLa. Stat. Ann. tit. 10, \& 1109(a) (Supp. 1970-71).

85. Miranda v. Arizona, 384 U.S. 436, 478-79 (1966).

86. CAL. WELF. \& INST'NS CODE §§ 625(c), 627.5 (West Supp. 1971).

87. New York does, however, provide that if an officer decides to question a juvenile, the officer must

take the child to a facility designated by the appropriate appellate division of the supreme court as a suitable place for the questioning of children and there question him for a reasonable period of time .... N.Y. FAM. CT. ACr § 724(b)(ii) (McKinney Supp. 1970-71).

The same statute also provides

(d) In determining what is a "reasonable period of time" for questioning a child, the child's age and the presence or absence of his parents or other person legally responsible for his care shall be included among the relevant considerations. Id. $\S 724(\mathrm{~d})$.

88. See In re Knox, 53 Misc. $2 d$ 889, 280 N.Y.S.2d 65 (Fam. Ct. 1967); In re Rust, 53 Misc. 2d 51, 278 N.Y.S.2d 333 (Fam. Ct. 1967).

89. In re Aaron D., 30 App. Div. 2d 183, 290 N.Y.S.2d 935 (1968). The same result was reached in an earlier case. In re William L., 29 App. Div. $2 d$ 182, 287 N.Y.S.2d 218 (1968). 
for questioning juveniles, and the duration of the questioning-eight hours-exceeded the court's estimate of a "reasonable period of time." 90 The reasoning underlying these decisions is that, in the absence of his parents or other persons legally responsible for him, a youth is incompetent to understand or waive his rights. ${ }^{91}$

Many other courts have also confronted Miranda problems in the context of the juvenile investigatory process. It has, for example, been held that Miranda warnings must be given to juveniles during the investigatory stage of a delinquency proceeding, ${ }^{92}$ as well as before any statements may be taken from the juvenile..$^{93}$ It has also been indicated that in the case of a juvenile more may be required than merely informing him of his right to counsel and right to remain silent. ${ }^{94}$ With regard to waiver of the juvenile's rights, some courts have required effective waiver by both the juvenile and his parents, ${ }^{95}$ others have said that presence of the parents is unnecessary, ${ }^{96}$ and still others have held that although the presence of parents is not essential for effective waiver the court will look at the totality of the circumstances to determine its validity. ${ }^{97}$

90. In re Nelson, 58 Misc. 2d 748, 750, 296 N.Y.S.2d 472, 474 (Fam. Ct. 1969).

91. Id. at 752-53.

92. In re Creek, 243 A.2d 49 (D.C. Ct. App. 1968).

93. In re Teters, 264 Cal. App. 2d 816, 70 Cal. Rptr. 749 (1968); In re Buros, 249 Cal. App. 2d 55, 57 Cal. Rptr. 124 (1967). Compare In re Acuna, 245 Cal. App. 2d 388, 53 Cal. Rptr. 884 (1966) with In re Castro, 243 Cal. App. 2d 402, 52 Cal. Rptr. 469 (1966). See also CAL. WELF. \& INST'NS CODE $\$ \S 625,627.5$ (West Supp. 1971), which now require that juveniles be informed of their constitutional rights (the enumerated rights are similar in tenor to the Miranda rights) before any questioning may take place.

94. In re Rambeau, 266 Cal. App. 2d 1, 72 Cal. Rptr. 171 (1968). In this case the court of appeals held a juvenile's confession inadmissible because it was taken during a period of unlawiul detention following an illegal arrest, and no attempt had been made to notify the youth's parents or to bring him without unnecessary delay before a juvenile authority. In addition, the court found that the questioning of the youth was offensive in nature. The court seemed to be examining the totality of the circumstances in a way that extends beyond the usual Miranda inquiry.

95. Freeman v. Wilcox, 119 Ga. App. 325, 167 S.E.2d 163 (1969).

96. In re Dennis M., 70 Cal. 2d 444, 450 P.2d 296, 75 Cal. Rptr. 1 (1969). In this case, the youth was a fifteen year-old boy of apparently normal intellect who had had prior encounters with the law.

97. Lopez v. United States, 399 F.2d 865 (9th Cir. 1968); West v. United States, 399 F.2d 467 (5th Cir. 1968), cert. denied, 393 U.S. 1102 (1969). In both of these cascs the youth was sixteen years old. The West case contains an enumeration of the circumstances to be considered: (1) age of the accused; (2) education of the accused; (3) knowledge of the accused as to both the substance of the charge, if any has been filed, and the nature of his rights to consult with an attorney and remain silent; (4) whether the accused is held incommunicado or allowed to consult with relatives, friends or an attorney; (5) whether the accused was interrogated before 
This discussion by no means exhausts the consequences of incustody treatment, ${ }^{98}$ but it does amplify the legal requirements that are being imposed on the treatment of juveniles immediately after they are brought into custody. It is these requirements, however, which also cast light on the procedures which should be followed in the process of deciding whether a juvenile should be taken into custody. In short, it indicates that the procedures required to be followed with regard to adults should also be applied to juvenile offenders.

\section{Reflections on the Emerging Juvenile Process}

As Gault emphasized, the primary function of the juvenile system is law enforcement, not, as some may feel, teaching manners to sassy children. ${ }^{99}$ From this point of view, the great majority of jurisdictions have no special procedures for the handling of young people, in spite of the fact that juveniles possess unique characteristics that set them apart from adults. ${ }^{100}$ Young people are, in addition, very impressionable and are particularly vulnerable to influence. ${ }^{101}$ When a youth confronts the police he may feel alone and regard the police as being demanding, judgmental, and possibly hostile. ${ }^{102}$

Officers who deal with juveniles should be given special training and experience. ${ }^{103}$ They must know a great deal about youth, about the problems that young people face, and must be able to recognize a youth who is in trouble and needs help. Especially where police are permitted to make the custodial detention decision, these officers must have at their disposal sufficient knowledge with which to wield the discretion effectively. Too, the officer ought to be aided, wherever

or after formal charges had been filed; (6) methods used in interrogation; (7) length of interrogations; (8) whether vel non the accused refused to voluntarily give statements on prior occasions; and (9) whether the accused has repudiated an extra judicial statement at a later date. 399 F.2d at 469.

98. For a summary treatment of other custodial problems, such as fingerprinting and search and seizure, see Ferster \& Courtless 589-608.

99. Ketcham, supra note 21 , at 1701.

100. Luger, The Youthful Offender, in TASK ForCe RePort: Juvenile DeLinquency 12021.

101. Paulsen 551.

102. Ketcham, supra note 47 , at 595.

103. Paulsen 551. See also Swanson 363-70; J. KeNNEY \& D. PuRsuit, supra note 51, at 43-44. Specialists, however, tend to be "professionalistic." For a discussion of the differences observed in relations between juveniles and, on the one hand, a "professional" department, and, on the other, a "nonprofessional" department, see Wilson, The Police and the Delinquent in Two Cities, in Controlling Delinguents 9-30. 
possible, by explicit departmental guidelines. While specificity is desirable, the guidelines must not be so rigid as to deprive the officer of flexibility in accommodating the great range of street situations. ${ }^{104}$

This discussion, despite efforts to the contrary, indicates that young people ought to be treated the same as adults in terms of receiving the protection of constitutionally guaranteed rights, and because they are different from adults they ought to be handled differently. This apparent inconsistency poses a Gordian knot of philosophical and legal entanglements. But it can be unraveled, if done slowly and perspectively. First it must be remembered that young people are different-indeed, this is the premise of the original juvenile court system. In addition, a broad jurisdictional approach is needed in order to reach the many kinds of problems evidenced by youth in "trouble." This broad approach is acceptable because youths need help when they engage in certain kinds of noncriminal behavior that, because of their young age, is detrimental to what society determines to be in their best interest or welfare. Yet, when it comes to initial police intervention in conduct, juveniles ought to be taken into custody on the street as the result of a police decision only under the same circumstances in which an adult would be arrested-that is, for violations of law. Any other jurisdiction that is to be exercised over juveniles-that is, "protective" jurisdiction, which owes its existence to the fact that juveniles are different-ought to be exercised by some authority other than the police. The permission of that authority should be a prerequisite to police intervention in the noncriminal conduct of youth, except in an instance where the child's immediate safety is endangered. ${ }^{105}$

The concern is, after all, with deprivation of liberty, which cannot be accomplished without satisfying the requirements of certain constitutional safeguards. For it is true, as the Supreme Court said in Gault, that "neither the Fourteenth Amendment nor the Bill of Rights is for adults alone." 106 What is therefore required is that juveniles be accorded the same constitutional protections enjoyed by adults. Because they are singularly sensitive, impressionable, and vulnerable in ways that adults are not, they must be handled with a great deal more solicitude and circumspection. This approach is

104. Commission Report: The Challenge of Crime 78. See also P. Kenney \& D. PuRsulT, supra note 51, at 49.

105. See notes 70-74 supra and accompanying text.

106. 387 U.S. at 13. 
consistent with both the underlying concept of parens patriae-the state as "protector" - and the concept of the emerging "constitutionalized" juvenile process. ${ }^{107}$ Gault was indeed revolutionary, ${ }^{108}$ and though some may grumble that the juvenile court has become a "miniature criminal court," few voices seriously decry the revolutionary change taking place in the juvenile process. ${ }^{109}$

What is involved in this movement is not a complete abandonment of an old philosophy but simply a new means of carrying it vut:

These challenges to the departure from procedural regularity in the juvenile courts make the case for bringing juvenile court procedures into closer harmony with our fundamental commitments to due process of law. What is entailed is not abandonment of the unique qualities of the juvenile court or adoption of the precise model of the criminal trial in all its particulars . . . . What is entailed is accommodation of both goals by establishing procedures permitting the court effectively to pursue humane and rehabilitative aims within the framework of a system that recognizes the indispensability of justice in any coercive government venture into the lives of individuals. ${ }^{110}$

The "coercive governmental venture into the lives of individuals" begins with the policeman, when he sees a violation of the law or merely senses that "something is not right" or feels that a youth is "endangered by his surroundings"-in essence, when state power is brought to bear against the individual's liberty by an officer's

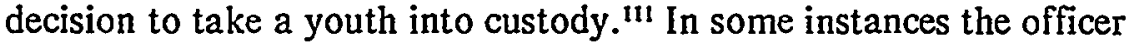
ought not make the decision at all. That power properly belongs-or should belong-to some other authority, and in.cases in which the decision is made by the officer, he ought to be better prepared to make it.

107. See note 31 supra.

108. Ketcham, supra note 21 , at 1718.

109. Though the voices are few, they are heard in high places. See 397 U.S. at 375-76; 387 U.S. at $78-81$.

The moment we insist upon affording children-whether in home, school, civic and legal matters, or court-all constitutional liberties, rights, and safeguards afforded to adults, we open the door to a number of undesirable, potentially dangerous factors so that, instead of protecting the child, as is our honest intention, we may be doing him a disservice, an injustice. Injustice to a child should be unforgivable and unthinkable. Justice to a child must be more than due process of law and fair legal treatment. Alexander, Constitutional Rights in the Juvenile Court, in Justice 82, 92.

110. TASK Force Report: Juvenill: DeLnquency 31. See also 387 U.S. at 21-22, which urges that due process is consistent with the philosophical aims of the juvenile court.

111. Police discretion is more fully explored in a conceptualistic manner in Tieger, supra note 36 . 


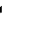

